\title{
Digital Manufacturing in Small Companies Environment
}

\author{
$1^{\text {st }}$ Anna Šmeringaiová ${ }^{1}, 2^{\text {nd }}$ Slavko Pavlenko ${ }^{2}, 3^{\text {nd }}$ Marek Wittner $^{3}, 4^{\text {nd }}$ Peter $\breve{S} m e r i n g a i^{4}$ \\ \{anna.smeringaiova@tuke.sk', slavko.pavlenko@tuke.sk², marek@decran.eu ${ }^{3}$, \\ peter.smeringai@tuke.sk $\left.{ }^{4}\right\}$
}

\begin{abstract}
Faculty of Manufacturing Technologies of the Technical University of Kosice with a seat in Prešov, Bayerová 1, 08001 Prešov, Slovakia ${ }^{1,2,4}$, DECRAN - SK, s.r.o., Sládkovičova 2545, 01701 Považská Bystrica, Slovakia $^{3}$
\end{abstract}

\begin{abstract}
Customization and digitization of production processes represent the current trend in the development of industrial production, to which larger and smaller companies have to adapt. Especially in small company environments it is a challenging process of modifications. Companies do not have their own capacities for the preparation and implementation of these changes. This opens up the space for company collaboration with research centers and universities. An example of such cooperation based on the current needs and possibilities of a small evolving engineering company is described in the article.
\end{abstract}

Keywords: Digital Manufacturing, Optimisation, Digitisation, Automation, Simulation.

\section{Introduction}

Customization and digitization of manufacturing processes are current trends in the development of industrial production. Customization, id est design and production according to the customer's individual requirements at the cost of a standard product, requires shorter development, production and delivery times. Digitization is focused on production management, process planning, optimal technology selection and digital data analysis.

Through the Industry 4.0 concept, companies create their own strategies to stay on the market and increase their competitiveness. There is no universal guidance on when, where and how to realize the changes. In general, it is recommended, especially in small business environments, to start with smaller projects. The preparation and realization of changes requires a team with creativity, good theoretical knowledge, practical experience, sufficient time and financial resources. This opens up the space for company collaboration with research centers and universities. Collaboration on common projects is based on the current needs of manufacturing companies. While companies are bringing practical experience and investment into the common project, universities are the carriers of new trends and information. An example of such cooperation is a common search for a productive solution for optimizing the production of DECRAN_SK, Ltd. Within this project company DECRAN_SK, Ltd. is cooperating with the Faculty of Manufacturing Technologies of the Technical University in Košice, with a seat in Prešov. 


\section{Possibilities of realisation of Digital Manufacturing in a Small Company Environment}

Company DECRAN_SK, Ltd. is a small developing organisation. The company's production program includes safety industrial steel doors and windows. $90 \%$ of the total production volume represents of customized production. Production in the required quality and the operational fulfillment of different customer requirements is a necessary condition for dealing with competition on the market.

The ambition of the company is also to expand to European markets, which requires increased labor productivity and increased production volume. A strategic plan for the gradual digitization of the entire manufacturing process was accepted to optimize production and gradually move to Digital Manufacturing. Digital Manufacturing is the use of an integrated computer system that includes simulations, three-dimensional visualization, analysis, and various tools to help with the activities as product design and process management at the same time. Management of DECRAN-SK, Ltd. is aware of the importance of digitization. Since the introduction of digital elements into manufacturing processes and manufacturing facilities, it is expected that the use of production facilities, human resources and expenses will significantly improve.

Because it is a small company that does not have sufficient human resources to solve the tasks related to the preparation and realisation of the process of implementing the changes to production, the management of the company approached to the Faculty of Manufacturing Technologies of the Technical University in Košice, based in Prešov, with a cooperation offer.

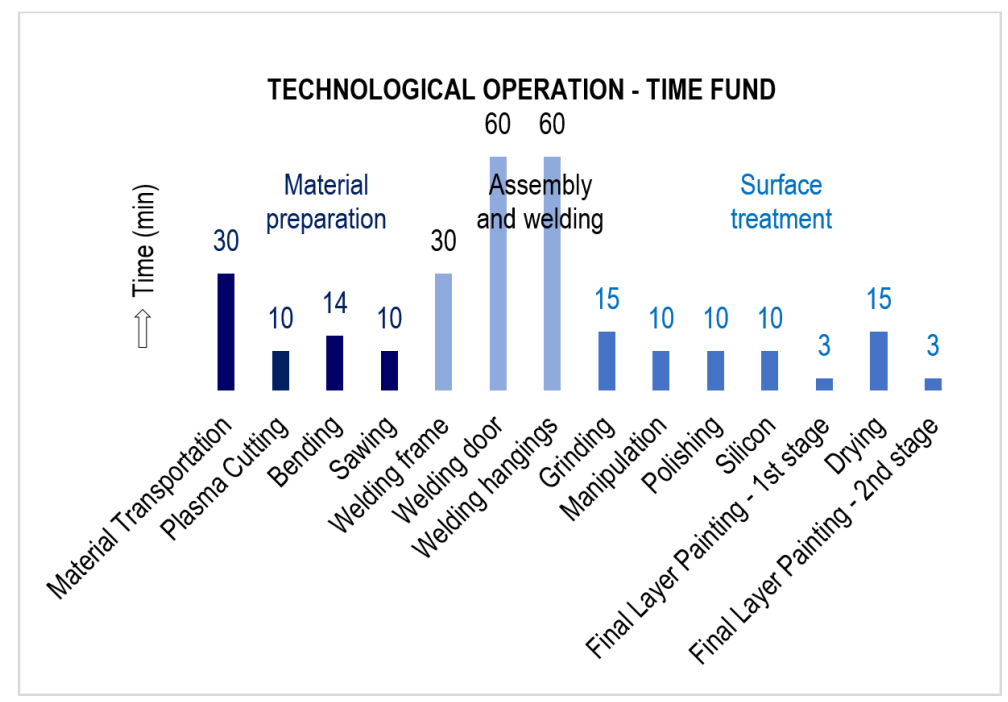

Fig. 1. Time Fund of Technology Operations - Type II Single doors. [5]

The following forms of cooperation were applied: professional consultations, elaboration of various analyses, solving individual problems by solutions of diploma theses. A detailed analysis of the current supply and demand status, work organization, production process, lifecycle of selected product types was made. For example, Figure 1 shows the technology times for the major technological operations for the production of single-wing type II. doors. 
The charts do not include the times for side operations (production preparation, interoperational transportation, packaging).

As input data, all available data on company organizational structure, orders, material orders and technical production assurance were used. These company data existed in a variable form but they were not analyzed and interconnected. Shortcomings were defined in the organizational structure, technological process and technical production security. The basic concept of the process of digitization of production was determined. The exact specification of the tasks solved in cooperation with KNMTS FVT TUKE was elaborated. The themes of the diploma theses, focused on the digitization of the technical documentation, the design and solution of the organizational changes and the solution of the automation of the individual workplaces, were suggested. [13], [14]

\subsection{Software support for company internal processes}

A major first step on the way to optimize production and business processes was to provide tools for mutual communication and exchange of information at all levels of the company - starting with management and ending with the distribution of finished products. The solution was to use appropriate data processing and production control software and place all data into a single and secure cloud. Autodesk Inventor Professional's 3D CAD software has been purchased and put into practice, for the configuration of 3D digital prototypes and for the technical preparation of production. The Jobboss software has been implemented to manage production related to financial management, distribution, sales and customer relationship management.

\subsection{Digitisation of technical documentation}

Data arrangement and introduction of data management system is the first step in Digital Manufacturing. In this case, the first step was the digitisation of technical documentation. The complete drawing documentation for all types of doors and windows is continuously processed using Autodesk Inventor Professional 3D graphical system and along with the technological procedures stored in the Autodesk Vault database program.

\subsection{Automation of the technical documentation}

Autodesk Inventor Professional supports parametric modeling as an effective approach to computer design. A new order acceptance system has been developed, which uses the automation elements in the processing of technical documentation. For selected standard door types, complex parametric models (iAssembly) have been developed, whose can be customized according to customer requirements using a special form within the scope of defined possible changes and parameters. Defined are optional items: door height and width, type of door, door orientation and requirements for special additional and safety features, handles, windows, custom grids, and the like. Once a form is completed and validated, the door model is automatically generated according to customer requirements with complete drawing documentation.

The first step in creating parametric models is generally to identify all possible alternatives of the product outcome including all possible components, shape elements and dimensions.[15] For example, in case of iAssembly modeling of type II door with safety door latch, twelve different variants have to be taken into account: 
1/2 Single door left / right without burglar protection bar and without padlock - Figure 1c.

3/4 Single door left / right with burglar protection bar and without padlock.

5/6 Single door left / right with burglar protection bar and with padlock - Figure $\mathbf{1 b}$.

7/8 Dobule door left / right without burglar protection bar and without padlock.

9/10 Dobule door left / right with burglar protection bar and without padlock - Figure 1d.

11/12 Dobule door left / right with burglar protection bar and with padlock - Figure 1a.

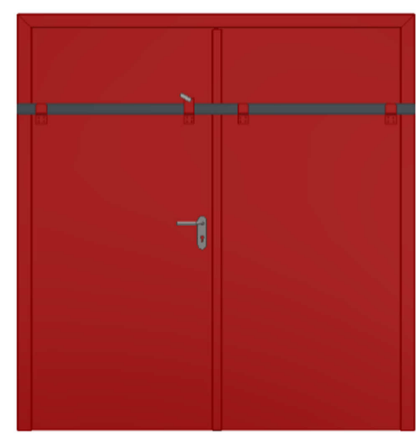

a)

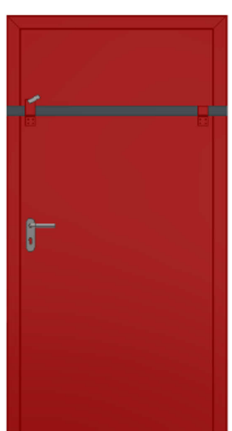

b)

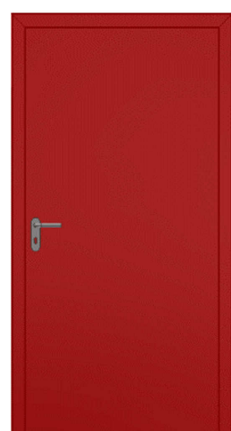

c)

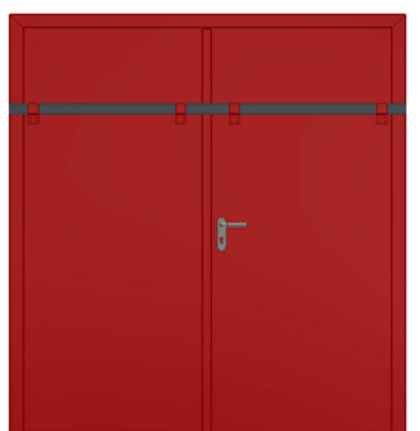

d)

Fig. 2. Design alternatives Type II doors. [11]

\subsection{Certification of products}

In 2016, DECRAN-SK, Ltd. asked TSUS in Nitra for a series of laboratory tests and results respectively resulting protocols were the base for the declaration of manufacturer's DECRANSK parameter within the CE. Obtaining a certificate by which a firm declares high quality work and products is the key to establish itself in the EU markets. The course of the certification process has helped to identify bottlenecks in manufacturing process and a number of technological deficiencies - inadequate quality of the drop threshold strip, inefficient door sealing, strength deficiencies (fine deformation under elevated pressure) within the top and bottom of the wing. Once removed, the company can achieve a higher financial return on production and, consequently, better economic efficiency of the company's operations.

\subsection{Expansion of manufacturing premises and space arrangement changes}

The planned increase in production volume required expansion of manufacturing premises Figure 3. With regard to the extension of the original manufacturing area - the production halls $1,2,5$ to the premises of the production halls 3 and 4, a new layout of the manufacturing plant was developed.

The change of layout is linked to the proposed changes in logistics of production and interoperational transport. Except for original warehouses (Figure 3 - Hall 1) will be among the technological workplaces (Welding zone - Grinding zone and Grinding zone - Paiting zone) established interim storage zones, (Figure 3 - Hall 3, 4, 5) equipped with special handling equipment. In the warehouse (Figure 3 - Hall 5) there will be reserved room for storing standardized doors for direct sales. 


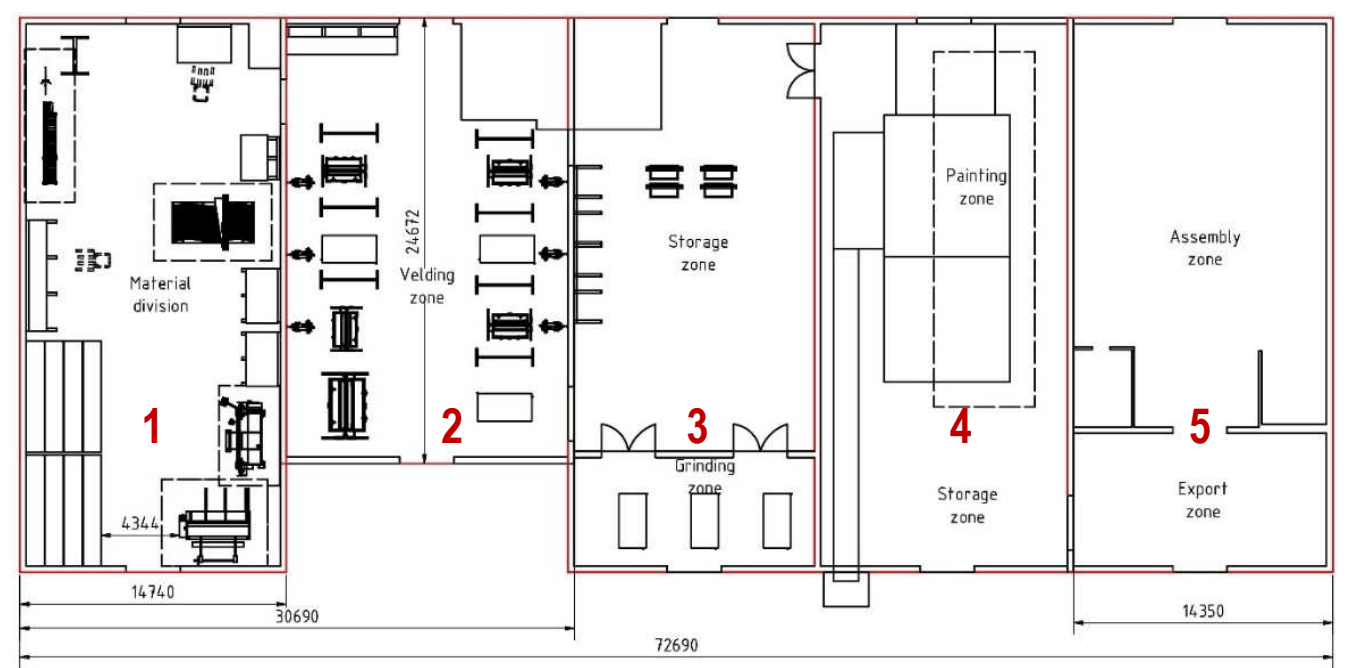

1 - Material division, 2 - Welding zone, 3 - Storage zone, Grinding zone, 4 - Paiting zone, 5 - Export control, Packaging, Export

Fig. 3. Design of layout of the production plant. [5]

\subsection{Design of material storage automatization}

Materials storage company DECRAN-SK, Ltd. performs several functions: material acceptance and expenditure, storage of semi-finished products and tools, separation and preparation of semi-finished products for welding. The main lack of efficient warehouse operation was the inappropriate arrangement of the machine park and storage areas with shelves for storing semi-finished products, tools and spare parts and manual handling of the material.

New layout solutions for warehouse space and replacement of machinery with handling and automation technology - selection of proposed solutions:

Alternative 1. By changing the layout of the machines and storage areas, two working zones have been created with a view to better warehouse logistics. - Figure 4. The aim is to eliminate traffic collisions in moving material, shorten the transport distances and the time needed to realize downstream technological operations of production preparation. As a result of dispositional changes, the efficiency of warehouse activities should be increased by $10 \%$ and the workers and machinery downtimes should be significantly reduced.

Part of the design was implementation of handling machine equipment, automation technique and interconnection between storage control systems and company control software. Forklift stackers with combustion engine were replaced by modern electric forklift stackers. All storage racks are equipped with compression weight modules. Information system Jobboss should be replaced by control software MS Dynamics NAV, which can be linked to the control systems of forklift trucks and compression weighing systems via RFID systems. The result should be a continuous, current overview of stock inventory status, its tracking according to the set parameters and automatically generated reports in the case of over-stock or under-stock inventory. Thanks to an overload alarm, the workers safety is also protected against the collapse of shelves under excess weight of material. 
Alternative 2. The handling of material is ensured by pillar cranes and forklifts. A current information system will be used to record stock inventory status.

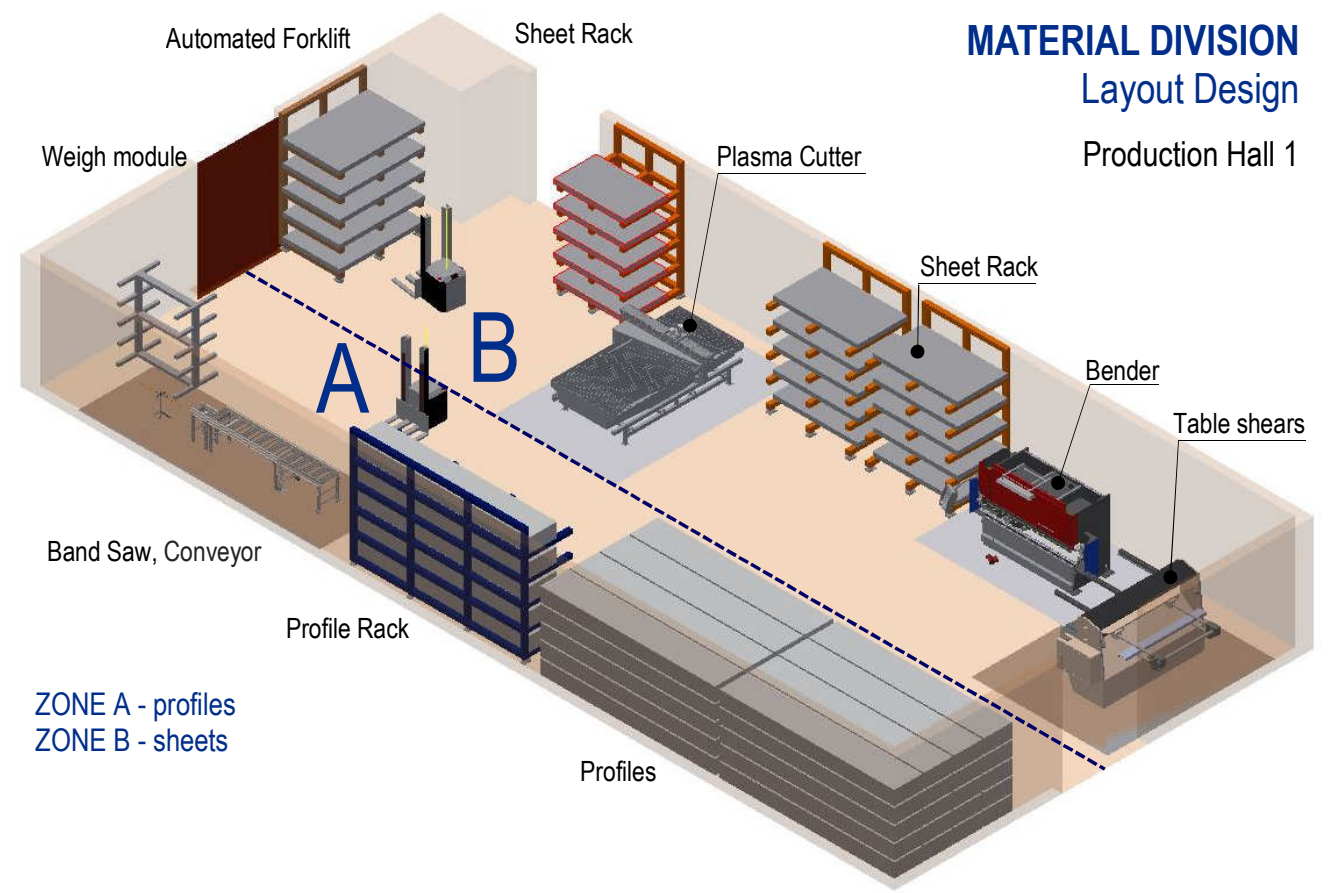

Fig. 4. Storage and preparation of material. [3]

\subsection{Automation of technological workplaces}

Significant innovation changes are also planned at individual technological sites:

Robotic cells for assembly and welding. The company plans to optimize welding and assembly workplaces. The base of each production cell will be the industrial robot and special mounting and positioning devices and manipulators. Since the implementation of robotized workplaces into production, it is expected to increase production, reduce production costs, eliminate heavy manual labor, increase work safety and increase the quality of products.

Semi-automatic paint spraying line. The high-quality surface finish of the windows and doors produced is a prerequisite for their perfect appearance and guaranteed life cycle. The new semi-automatic paint spraying line installed in Hall 4 (Figure 3), designed specifically for the needs of DECRAN-SK, s.r.o., enables a complete surface finish of windows and doors: grinding, degreasing, manual paint application, drying. The painting process is monitored by an automated ECO control system. Spraying line hall area and all adjoining premises are provided with automatic safety features and meet all prescribed conditions and precautions. 
The benefit of a new spray line compared to the original temporary line will be to significantly increase the efficiency of the production process, high product surface quality, line safety and environmental protection. The benefit of the new paint shop is also a significant saving in the funds currently being used to transport the doors to the Belgian parent company where final finishing is being done. The cost of packaging, exporting, transporting and subsequently spraying the door in Belgium, packaging and exporting to the customer is eliminated.

\subsection{Computer simulation of production and logistics processes}

Computer simulation is an effective tool not only in the process of designing production and logistics processes, but also allows them to be continuously optimized directly in the realworld manufacturing process. As part of the preparation and processing of all the abovementioned changes, Autodesk Inventor Professional has created a virtual 3D model of production layout. In the initial realisation phase, the 3D model of the material stock was created - Figure 4. All proposed alternatives to the functional layout of the storage areas were verified by simulation. Based on simulation results, optimal layout was selected. Using functional simulation, it is possible to verify the fluency of planned warehouse operations for various set operating parameters and to detect shortcomings and possible time, personnel and space collisions.

The ambition is to gradually add all the upcoming and realized optimization changes of the whole production facility into the 3D model and create a copy of it (Digital Twin) working in the virtual world. The technology concept "Digital Twin" is created by linking physical reality and its own digital copy. In the case of a small company with predominantly custom-made production, it can have a multiple recovery effect. It also makes it possible to shorten and streamline material handling processes, optimize logistics and personal performance and give flexibility to production and logistics systems.

\subsection{Concept of personnel policy oriented to skilled workers}

The competitiveness of most companies in Slovakia is based on innovative solutions. The creation and use of innovation requires skilled workers. Their lack, respectively. their absence in the process of creating and introducing innovative changes into production was solved by DECRAN-SK, s.r.o. working with KNMTS FVT Prešov. The concept of acquiring and stabilizing new qualified employees who are able and willing to adapt to change in a changing company environment, creatively use and further develop their knowledge and digital skills has been developed. For mentoring and training of employees in production, a virtual simulator is also planned in the future.

\section{Conclusion}

For the modern dynamic market it is characteristic that the basic products are manufactured and delivered in various variants, tailored to the needs of customers. In the manufacturing process, it is necessary to handle a huge amount of data related to the initial design of the product, its structure, manufacturing, sales, customer service and final recycling. The optimal preparation for the practical realization of such production enables the concept of a digital business. Most companies already use software, related visualizations and communication 
technologies in separate units operating in individual segments. The strategic path of not only large businesses, but also small businesses, leads to complete integration of the entire production process, including development or after-sales service, through digitisation and the Internet.

Acknowledgments. This research was supported by the Ministry of Education of the Slovak republic, through grants KEGA 051TUKE-4/2018 „Implementing Smartphones to Improve CAE Technology Teaching Process in Context of Industry 4.0“.

\section{References}

[1] Balog, M., Knapčíková, L., Husár, J.: Plánovanie v strojárskej výrobe. 1. vyd. Brno: Tribun EU, 2016. 86 p.. ISBN 978-80-263-1078-5.

[2] Dušan Dorčák, D., Július Lišuch, J. Romana Hricová, R.: Total logistic Plant Solutions. In: TEM Journal. Vol. 5, no. 1 (2016), p. 97-103. ISSN 2217-8309

[3] Grega, J.: Design of material storage automatization. Diploma work. (2018)

[4] Hricová, R.: Employment among young people and graduates in terms of personnel strategy. In: Acta Tecnología. Roč. 3, č. 3 (2017), s. 1-6. ISSN 2453-675X

[5] Juhas, M.: Surface processing automatization of the products. Diploma work. (2018)

[6] Knapč́́ková, L., Husár, J.: Typology of manufacturing flexibility in the engineering industry: A review. In: Acta Tecnología. Roč. 2, č. 3 (2016), s. 13-16. ISSN 2453-675X

[7] Maščenik, J.: Experimental determination of cutting speed influence on cutting surface character in material laser cutting. In: MM Science Journal. Vol. 2016, no. September (2016), p. 960-963. ISSN 1803-1269

[8] Matisková, D.: Inovácie v riadení podnikových procesov. 1. vyd. Košice: TU, 2016. 99 p.. ISBN 978-80-553-3023-5.

[9] Monkova, K. et al.: Application of simulation for product quality enhancement. In: IMEIA 2016. Lancaster: DEStech Publications, 2016 P. 216-220. ISBN 978-1-60595-345-8

[10] Pastucha, P. et al.: Technological Devices Design Using Simulation Tool. In: ICECTT 2015. Amsterdam: Atlantis Press, 2015 P. 139-142. ISSN 2352-5401

[11] Popel, D.: Parametrization of product model. Diploma work. (2018)

[12] Šmeringaiová, A.: Modeling and simulation of mechanisms. In: Quaere 2014: recenzovaný sborník prríspěvků vědecké interdisciplinární mezinárodní vědecké konference doktorandů a odborných asistentů: vol. 4: 26. - 30. května 2014, Hradec Králové, Česká republika. Hradec Králové: Magnanimitas, 2014 P. 1465-1471. ISBN 978-80-87952-04-7

[13] Šmeringaiová, A., Murčinková, Z.: Computer aided educational process in the design of technical systems. In: EPF 2017. Hradec Králové: Magnanimitas, 2017 P. 288-295. ISBN 978-8087952-21-4

[14] Šmeringaiová, A., Pavlenko, S.: Implementation of CA - technology in teaching: Computer aided design. In: DIDMATTECH 2017. Trnava: University in Trnava, 2017 S. 126-134. ISBN 978-80-568-0029-4

[15] Wittner, M. Automatizácia a parametrizácia v priemysle [online]. 2017. [2017-05-28]. From: $\underline{\text { http://ifxservices.com }}$ 